\title{
OVULATION INDUCTION AND ANTIFERTILITY EFFECTS OF AN LH-RH ANALOGUE (AY"-25,205) IN CYCLIC RATS
}

\author{
U. K. BANIK AND M. L. GIVNER \\ Department of Endocrinology and Immunochemistry, \\ Ayerst Research Laboratories, P.O. Box 6115, Montreal, Canada
}

(Received 25th November 1974)

\begin{abstract}
Summary. Pro-oestrous rats, treated with fluphenazine dihydrochloride to block ovulation, were used to compare the ovulation-inducing activity of synthetic LH-RH with one of its analogues, [D-Ala ${ }^{6}$, des-Gly- $\mathrm{NH}_{2}{ }^{10}$ ]LH-RH ethylamide (AY-25,205). The lowest dose of LH-RH which produced a significant response was $125 \mathrm{ng}$ compared with 2.9 nig AY25,205 . Statistical analysis of the data showed that AY-25,205 was approximately thirty-six times more potent than LH-RH. Treatment with AY-25,205 also induced partial ovulation in metoestrous rats ( 80 or $160 \mathrm{ng} / \mathrm{rat}$ ) and apparently normal ovulation in dioestrous rats (10 to $160 \mathrm{ng} / \mathrm{rat})$. The compound $(160 \mathrm{ng}$ ) failed to induce further ovulation in oestrous rats which ovulated during the previous night. Advancement of premature ovulation in dioestrous rats with AY-25,205 prevented mating behaviour and pregnancy during the treatment cycle. The antifertility effect of the compound disappeared during the following cycle.
\end{abstract}

\section{INTRODUCTION}

Since the isolation, purification, characterization and synthesis of porcine LHand FSH-releasing hormone (Matsuo, Arimura, Nair \& Schally, 1971; Schally, Kastin \& Arimura, 1971), many investigators (see White, Hedlund, Rippel, Arnold \& Flouret, 1973) have successfully synthesized this decapeptide. Potent analogues of this decapeptide have also been synthesized and their potencies compared to that of synthetic LH-RH with respect to hypophysial LH- and FSH-release (Coy \& co-authors, 1974; Kastin \& co-authors, 1974; Arimura, Vilchez-Martinez \& Schally, 1974a; Arimura, Vilchez-Martinez, Coy, Coy, Hirotsu \& Schally, 1974b) and ovulation-inducing activity in rats (Fujino \& co-authors, 1974a, b). A synthetic LH-RH and a few of its analogues have also been synthesized in our laboratories (Immer, Nelson, Revesz, Sestanj \& Götz, 1974).

The purpose of this communication is to report the comparative capacity of synthetic LH-RH and one of its analogues (AY-25,205) to induce ovulation in pro-oestrous rats treated with fluphenazine dihydrochloride (FD). In this report, the results of induction of premature ovulation in metoestrous and dioestrous rats and the antifertility effects of AY-25,205 in female rats are also described. 


\section{MATERIALS AND METHODS}

Experiments were conducted on adult $(225 \pm 25 \mathrm{~g})$ 4-day cyclic SpragueDawley rats obtained from the Canadian Breeding Laboratories, St Constant, Quebec. The rats were maintained in an air-conditioned room $\left(24\right.$ to $25^{\circ} \mathrm{C}$; 45 to $50 \%$ humidity) and exposed to equal periods of light and darkness. Standard Purina Chow and water were freely available. At least six or more animals were used in each group.

For blocking ovulation, FD was administered subcutaneously $(500 \mu \mathrm{g} / 0 \cdot 2 \mathrm{ml}$ of $0.9 \%$ saline) between 14.15 and 14.30 hours on the day of pro-oestrus. For inducing ovulation in FD-treated rats, different single doses of the following two synthetic decapeptides were injected in $0.2 \mathrm{ml}$ of $0.9 \%$ saline intravenously between 15.00 and 15.30 hours on the same day: (1) synthetic LH-RH: H-PyrHis-Trp-Ser-Tyr-Gly-Leu-Arg-Pro-Gly- $\mathrm{NH}_{2}$, (2) LH-RH analogue (AY25,205) : H-Pyr-His-Trp-Ser-Tyr-D-Ala-Leu-Arg-Pro-NH- $\mathrm{CH}_{2}-\mathrm{CH}_{3}$. Control rats received the vehicle only.

For experiments on the induction of ovulation in untreated rats, $160 \mathrm{ng}$ AY-25,205/rat was injected intramuscularly between 15.00 and 15.30 hours on the appropriate day of the cycle so that all stages were represented. Similarly, different doses of AY-25,205 were administered intramuscularly to metoestrous and dioestrous rats in order to establish the minimum effective dose (MED) for premature induction of ovulation. Evidence for ovulation was obtained by counting microscopically freshly shed ova from the oviduct the morning after administration of the decapeptides, according to the method described by Banik \& Herr (1969).

For exploring the antifertility and post-antifertility effects, different doses of AY-25,205 were administered intramuscularly between 15.00 and 15.30 hours to dioestrous rats. Each treated and control rat was allowed to cohabit with a fertile male for 3 consecutive days and nights. Females were inspected on the morning after pairing for a mucus plug or spermatozoa in the vaginal smear, and the number of uterine implantations were counted 9 days after coitus or the last day of cohabitation.

Statistical analysis of the number of rats which ovulated, mated and became pregnant was made using the fourfold contingency test tables of Mainland \& Murray (1952); the average number of ova or implantations in each group was compared with those of the appropriate control and other groups by using Student's $t$ test.

\section{RESULTS}

\section{Induction of ovulation in pro-oestrous rats treated with $F D$}

It is evident from the results in Table 1 that FD blocked ovulation in 19/20 rats, and increasing doses of LH-RH and AY-25,205 induced ovulation in rats treated with FD. Treatment with LH-RH (125 ng or more) induced ovulation in a significant number of rats, when compared to control rats injected with FD and saline, whereas only $2.9 \mathrm{ng}$ or more of AY-25,205 was needed for a comparable effect (Table 1). The relative potency of LH-RH and AY-25,205 was determined by probit analysis (Finney, 1947) and the latter compound was 
Table 1. Induction of ovulation with a synthetic LH-RH or AY-25,205 in pro-oestrous rats treated with fluphenazine dihydrochloride

\begin{tabular}{|c|c|c|}
\hline Treatment & $\begin{array}{l}\text { No. of rats } \\
\text { ovulating }\end{array}$ & $\begin{array}{c}\text { No. of ova } \\
(\text { Mean } \pm \text { S.E. })^{*}\end{array}$ \\
\hline $\begin{array}{l}\text { LH-RH (ng/rat) } \\
\text { Saline (control) }\end{array}$ & $10 / 10 * *$ & $11 \cdot 5 \pm 0.5$ \\
\hline $\begin{array}{c}\text { FD+saline } \\
\text { (control) } \\
16 \cdot 22 \\
31 \cdot 25 \\
62 \cdot 5 \\
125 \cdot 0 \\
187 \cdot 5 \\
250 \cdot 0\end{array}$ & $\begin{array}{l}1 / 10 \\
0 / 10 \\
1 / 10 \\
2 / 10 \\
8 / 10^{* *} \\
9 / 10^{* *} \\
10 / 10^{* *}\end{array}$ & $\begin{array}{l}9 \cdot 0 \\
0 \\
15 \cdot 0 \\
9 \cdot 0 \\
7 \cdot 5 \pm 1 \cdot 1 \\
8 \cdot 2 \pm 0 \cdot 8 \\
10 \cdot 1 \pm 1 \cdot 2\end{array}$ \\
\hline $\begin{array}{l}\text { AY-25,205 (ng/rat) } \\
\text { Saline (control) }\end{array}$ & $10 / 10 * *$ & $11.5 \pm 0.5$ \\
\hline $\begin{array}{c}\text { FD+saline } \\
\text { (control) } \\
0.97 \\
1.95 \\
2.9 \\
3.9 \\
7.7\end{array}$ & $\begin{array}{c}0 / 10 \\
1 / 10 \\
2 / 10 \\
7 / 10^{* *} \\
9 / 10^{* *} \\
10 / 10^{* *}\end{array}$ & $\begin{array}{l}0 \\
10 \cdot 0 \\
3.5 \\
11 \cdot 0 \pm 0.7 \\
11 \cdot 4 \pm 1 \cdot 0 \\
10 \cdot 6 \pm 1 \cdot 2\end{array}$ \\
\hline
\end{tabular}

FD, fluphenazine dihydrochloride.

* Calculated from the rats which ovulated. Statistical comparisons were made between different groups when feasible.

** $P<0.01$ versus FD+saline control group.

approximately $36.33 \pm 6.8$ (S.E.) times more potent than the former; moreover, when the log-dose of each compound was plotted against the proportion of rats ovulating, two parallel lines were obtained (Text-fig. 1).

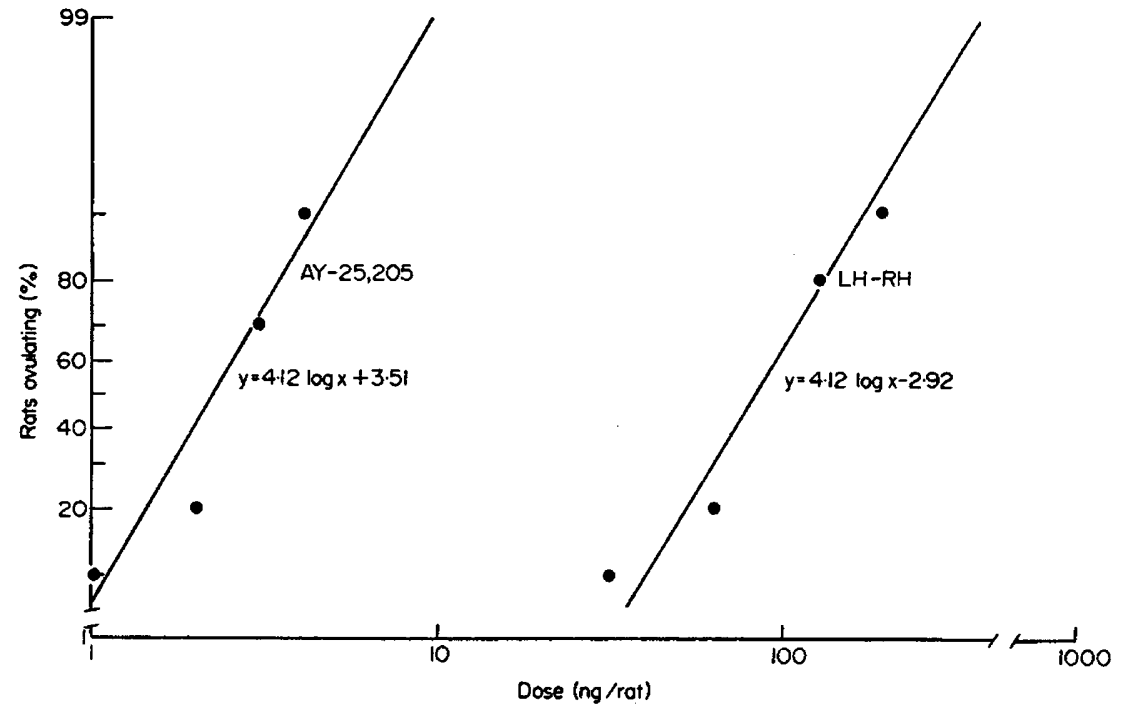

TExT-FIC. 1. The relative potency of AY-25,205 compared to that of LH-RH in prooestrous rats treated with fluphenazine dihydrochloride. 
Induction of ovulation with $A Y-25,205$ administered on different days of the cycle

A single dose of AY-25,205 was unable to induce further ovulation in oestrous rats which ovulated during the previous night, but this compound was effective in inducing premature ovulation in metoestrous and dioestrous rats (Table 2).

Table 2. Attempted induction of ovulation with AY-25,205

(160 $\mathrm{ng} / \mathrm{rat}$ ) in oestrous, metoestrous, dioestrous and prooestrous rats

\begin{tabular}{llcc}
\hline $\begin{array}{c}\text { Stage of } \\
\text { cycle }\end{array}$ & \multicolumn{1}{c}{ Treatment } & $\begin{array}{c}\text { No. of rats } \\
\text { ovulating } \dagger\end{array}$ & $\begin{array}{c}\text { No. of ova } \\
\text { (Mean } \pm \text { S.E. })\end{array}$ \\
\hline Oestrus & Saline (control) & $0 / 6$ & 0 \\
& AY-25,205 & $0 / 7$ & 0 \\
Metoestrus & Saline (control) & $0 / 6$ & 0 \\
Dioestrus & AY-25,205 & $7 / 10^{* *}$ & $2 \cdot 3 \pm 0.5$ \\
& Saline (control) & $0 / 12$ & 0 \\
Pro-oestrus & AY-25,205 & $10 / 10^{* *}$ & $10 \cdot 1 \pm 1 \cdot 0^{* *}$ \\
& Saline (control) & $6 / 6$ & $11 \cdot 5 \pm 1 \cdot 5^{* *}$ \\
& AY-25,205 & $8 / 8$ & $13 \cdot 4 \pm 0 \cdot 5^{* *}$ \\
\hline
\end{tabular}

** $P<0 \cdot 01$.
$\dagger$ Versus saline control of respective group.
$\ddagger$ Versus AY-25,205 metoestrous group.

The mean number of ova in the rats treated during metoestrus was lower than that in the dioestrous and pro-oestrous rats $(P<0.01)$. All pro-oestrous animals treated with saline or with AY-25,205 ovulated.

Induction of premature ovulation in metoestrous and dioestrous rats with an increasing dose of $A Y-25,205$

Premature ovulation was induced by a single dose ( $80 \mathrm{ng} / \mathrm{rat}$ ) of AY-25,205 in 6/10 metoestrous rats, though the mean number of ova detected was lower than in pro-oestrous rats treated with saline (Table 3 ). In dioestrous rats, a dose of $>10 \mathrm{ng} \mathrm{AY-25,205}$ induced ovulation in all but one rat. None of the dioestrous conrol rats or those receiving the lowest dose of AY-25,205 ovulated.

Table 3. The induction of premature ovulation in metoestrous and dioestrous rats with a single increasing dose of AY-25,205

\begin{tabular}{|c|c|c|c|c|}
\hline \multirow{2}{*}{ Treatment } & \multicolumn{2}{|c|}{ Metoestrous rats } & \multicolumn{2}{|c|}{ Dioestrous rats } \\
\hline & $\begin{array}{c}\text { No. } \\
\text { ovulating }\end{array}$ & $\begin{array}{c}\text { No. of ova } \\
(\text { Mean } \pm \text { S.E. })^{*}\end{array}$ & $\begin{array}{c}\text { No. } \\
\text { ovulating }\end{array}$ & $\begin{array}{c}\text { No. of ova } \\
(\text { Mean } \pm \text { S.E. })^{*}\end{array}$ \\
\hline Saline (control) & $0 / 6$ & 0 & $0 / 10$ & 0 \\
\hline $\begin{array}{l}\text { AY- } 25,205(\mathrm{ng} / \mathrm{rat}) \\
2 \cdot 5 \\
10 \\
20 \\
40 \\
80\end{array}$ & $\begin{array}{l}0 / 10 \\
0 / 10 \\
0 / 10 \\
0 / 10 \\
6 / 10^{* *}\end{array}$ & $\begin{array}{c}0 \\
0 \\
0 \\
0 \\
4 \cdot 7 \pm 1 \cdot 0\end{array}$ & $\begin{array}{c}0 / 10 \\
10 / 10^{* *} \\
9 / 10^{* *} \\
10 / 10^{* *} \\
10 / 10^{* *}\end{array}$ & $\begin{array}{c}0 \\
7 \cdot 3 \pm 0.8 \\
10 \cdot 3 \pm 0.8 \\
11 \cdot 0 \pm 1.4 \\
9.0 \pm 1.2\end{array}$ \\
\hline
\end{tabular}

* See Table 1 for statistical treatments.

$* * P<0.01$ versus saline control. 
Antifertility and post-antifertility effects of $A Y-25,205$ in female rats

The results presented in Table 4 show that $\geqslant 10 \mathrm{ng}$ AY-25,205 administered on the day of dioestrus interfered with the mating behaviour during the ensuing pro-oestrus and oestrus. No such significant antifertility effect was seen in the control rats or in those treated with $2.5 \mathrm{ng} \mathrm{AY}-25,205$. Except in these two groups, there was a change in the vaginal smear cytology during the treatment cycle; the vaginal smears from rats receiving the higher doses of AY-25,205 did not contain the expected predominance of squamous cells on the morning of oestrus. During the ensuing cycle, however, most of the rats treated with AY-25,205 and all of the remaining controls mated with fertile males during the night of pro-oestrus and became pregnant with a normal number of implantations (Table 4). The pro-oestrous type of vaginal cytology was found 1 day earlier than usual.

Table 4. Antifertility and post-antifertility effects of AY-25,205 in female rats

\begin{tabular}{|c|c|c|c|c|c|c|}
\hline \multirow[b]{2}{*}{ Treatment } & \multicolumn{3}{|c|}{ Antifertility effect } & \multicolumn{3}{|c|}{ Post-antifertility effect } \\
\hline & $\begin{array}{l}\text { No. of } \\
\text { rats mated }\end{array}$ & $\begin{array}{l}\text { No. of } \\
\text { rats pregnant }\end{array}$ & $\begin{array}{c}\text { Implantations } \\
(\text { Mean } \pm S . E .)^{\dagger}\end{array}$ & $\begin{array}{l}\text { No. of } \\
\text { rats mated }\end{array}$ & $\begin{array}{l}\text { No. of } \\
\text { rats pregnant }\end{array}$ & $\begin{array}{l}\text { Implantations } \\
(\text { Mean } \pm S . E .) \ddagger\end{array}$ \\
\hline Saline (control) & $8 / 10$ & $8 / 8$ & $11 \cdot 1 \pm 0 \cdot 4$ & $2 / 2$ & $2 / 2$ & $10 \cdot 5 \pm 0.1$ \\
\hline $\begin{array}{c}\text { AY-25,205 (ng/rat) } \\
2 \cdot 5 \\
10 \\
20 \\
40 \\
80\end{array}$ & $\begin{array}{l}7 / 10 \\
1 / 10^{* *} \\
4 / 10^{*} \\
0 / 10^{* *} \\
0 / 10^{* *}\end{array}$ & $\begin{array}{l}5 / 7 \\
1 / 1 \\
2 / 4 \\
0 / 0 \\
0 / 0\end{array}$ & $\begin{array}{c}12 \cdot 0 \pm 0 \cdot 1 \\
4 \cdot 0 \\
3 \cdot 5 \\
0 \\
0\end{array}$ & $\begin{array}{c}2 / 3 \\
9 / 9 \\
6 / 6 \\
10 / 10 \\
10 / 10\end{array}$ & $\begin{array}{l}2 / 2 \\
9 / 9 \\
6 / 6 \\
10 / 10 \\
10 / 10\end{array}$ & $\begin{array}{c}13 \cdot 0 \\
10 \cdot 6 \pm 0 \cdot 4 \\
10 \cdot 8 \pm 0 \cdot 6 \\
10 \cdot 2 \pm 0 \cdot 4 \\
10 \cdot 2 \pm 1 \cdot 0\end{array}$ \\
\hline
\end{tabular}

$* P<0.05$ versus saline control group; ${ }^{*} * P<0.01$ versus saline control group.

$\dagger$ Calculated from the rats which mated. Statistical comparisons were made between different groups when feasible.

‡ Remaining rats which mated with fertile males within two subsequent cycles.

\section{DISGUSSION}

These experiments demonstrated that LH-RH and an analogue, AY-25,205, were effective in inducing ovulation in pro-oestrous rats treated with FD. Under these conditions, AY-25,205 was approximately thirty-six times more potent than $\mathrm{LH}-\mathrm{RH}$ in inducing ovulation. In a recent study (U. K. Banik, M. A. Hirsch and M. L. Givner, unpublished data), we were unable to induce ovulation in metoestrous and dioestrous rats with a single intravenous dose of $500 \mathrm{ng}$ LH-RH. It appears, therefore, that AY-25,205 is much more potent than LHRH in inducing ovulation in metoestrous and dioestrous rats. Fujino et al. (1974a) also observed that a synthetic preparation of an LH-RH analogue with an identical chemical structure to AY-25,205 was about fifty to eighty times more potent in inducing ovulation in dioestrous rats. In the present study, the $\mathrm{MED}_{100}$ of AY-25,205 administered intramuscularly was found to be approximately $10 \mathrm{ng} /$ dioestrous rat. Fujino et al. (1974b) calculated the $\mathrm{MED}_{50}$ of the same LH-RH analogue to be between $2 \cdot 0$ and $5 \cdot 1 \mathrm{ng} / 100 \mathrm{~g}$ body weight.

Recently, Coy et al. (1974) and Arimura et al. (1974b) have indicated that a synthetic compound, [D-Ala ${ }^{6}$, des-Gly- $\mathrm{NH}_{2}{ }^{10}$ ]-LH-RH ethylamide, chemically 
identical to AY-25,205, was many times more active than synthetic LH-RH in releasing hypophysial $\mathrm{LH}$ and FSH in ovariectomized rats treated with oestrogen and progesterone and also in immature male rats. The greater potency of AY-25,205 compared to LH-RH in inducing ovulation in prooestrous rats treated with FD and in normal dioestrous rats was, therefore, to be expected.

In laboratory animals (see Labhsetwar, 1973; Schwartz, 1974) as well as in women (Taymor, Berger, Thomson \& Karam, 1972), an interplay between FSH and LH is essential for ovulation. The advancement of ovulation with the appropriate dose of AY-25,205 in all dioestrous and even in some metoestrous rats in the present study, suggests that this compound is capable of releasing both FSH and LH for inducing final follicular growth and ovulation. By contrast, much higher doses (500 to $1000 \mathrm{ng} / \mathrm{rat}$ ) of synthetic LH-RH have been shown to be incapable of inducing satisfactory ovulation in metoestrous and early dioestrous rats (Morishita \& co-authors, 1974; U. K. Banik, M. A. Hirsch and M. L. Givner, unpublished data). These findings suggest that, unlike AY25,205 , synthetic LH-RH could not induce final maturation and rupture of nearly matured follicles, perhaps due to inadequate release of both FSH and LH.

In 4-day cyclic rats, the peak serum LH levels occur between 15.00 and 17.30 hours on the day of pro-oestrus (see Neguin, Talley, Mann \& Schwartz, 1974). Although the serum LH levels in FD-treated rats and in those treated with FD and synthetic peptides were not measured in the present study, it was presumed that the endogenous release of $\mathrm{LH}$ was blocked due to injection of FD before the critical period, and that the synthetic LH-RH and its analogue induced ovulation through the endogenous release of $\mathrm{LH}$ and perhaps also FSH.

In an earlier study (Humphrey \& co-authors, 1973), synthetic LH-RH, given intramuscularly in $\mu \mathrm{g}$ quantities or orally in $\mathrm{mg}$ amounts, induced ovulation in pro-oestrous rats treated with chlorpromazine. The lowest intramuscular dose of LH-RH inducing $100 \%$ ovulation $\left(\mathrm{MED}_{100}\right)$ in pro-oestrous rats treated with chlorpromazine was $1 \mu \mathrm{g}(3.7 \mu \mathrm{g} / \mathrm{kg}$ body wt). In the present study the lowest intravenous doses of synthetic LH-RH and AY-25,205 per rat for $\mathrm{MED}_{100}$ were 250 and $7.7 \mathrm{ng}$, respectively.

The antifertility effect with a single dose of AY-25,205 administered 1 day before the expected day of pro-oestrus was due to premature induction of ovulation (Tables 2, 3 and 4), and perhaps a change in ovarian steroidogenesis. This was evident from the disturbance in the vaginal cytology. On the expected day of pro-oestrus, despite showing predominantly vaginal epithelial cells, very few animals mated with fertile males. This was probably due to induction of premature rupture of follicles at 'a wrong time' thus causing a quick change from oestrogen-producing granulosa cells to progesteroneproducing luteal cells (Short, 1964). In a separate study (results not included in this report), we have observed that, by repeated medication of rats with AY-25,205, 1 day before the expected day of pro-oestrus, the antifertility effect could be demonstrated for a longer period of time without inducing anoestrus. In most of the animals, however, the cycle became 1 day shorter (U. K. Banik and M. L. Givner, unpublished data). 
Our preliminary studies demonstrate that, on a molar basis, AY-25,205 is not only more potent than LH-RH in inducing ovulation in rats but also possesses a different biological profile on the pituitary-ovarian system which may be useful for correcting infertility, controlling fertility and regulating the menstrual cycle in women and promoting fertility in farm animals.

\section{ACKNOWLEDGMENTS}

Synthetic LH-RH and its analogue (AY-25,205) were prepared by $\mathrm{Dr} \mathrm{H}$. Immer, Dr V. R. Nelson and Dr K. Sestanj of the Department of Chemistry, Ayerst Research Laboratories, Montreal. Efficient technical assistance in the biological experiments was provided by $\mathrm{Mr}$ W. Van Leenhoff and Mr P. Gauthier of our Department. Statistical analysis of the data was performed by Mr R. Paquette of our laboratories. Our sincere thanks are due to Dr R. Deghenghi for his keen interest in these studies.

\section{REFERENCES}

Arimura, A., Vilchez-Martinez, J. A. \& Schally, A. V. (1974a) In vivo comparison of LH-RH and FSH-RH activities of [Des-Gly $\left.{ }^{10}\right]\left[\right.$ Pro $^{9}$-ethylamide]-LH-RH, [Des-Gly $\left.{ }^{10}\right]\left[\right.$ Pro $^{9}$-propylamide]-LH-RH, and LH-RH using immature male rats. Proc. Soc. exp. Biol. Med. 146, 17-20.

Arimura, A., Vilchez-Martinez, J. A., Coy, D. H., Coy, E. J., Hirotsu, Y. \& Schally, A. V. (1974b) [D-Ala ${ }^{6}$, Des-Gly- $\mathrm{NH}_{2}{ }^{10}$ ]-LH-RH-ethylamide: a new analogue with unusually high LH-RH/ FSH-RH activity. Endocrinology, 95, 1174-1177.

BANIK, U. K. \& HeRR, F. (1969) Effect of medroxyprogesterone acetate and chlorpromazine on ovulation and vaginal cytology in a strain of 4-day cycling rats. Can. F. Physiol. Pharmac. 46, 573575.

Coy, D. H., Coy, E. J., Schally, A. V., Vilchez-Martinez, J., Hirotsu, Y. \& Arimura, A. (1974) Synthesis and biological properties of [D-Ala ${ }^{6}$, Des-Gly- $\left.\mathrm{NH}_{2}{ }^{10}\right]-\mathrm{LH}-\mathrm{RH}$ ethylamide, a peptide with greatly enhanced LH- and FSH-releasing activity. Biochem. biophys. Res. Commun. 57, 335340 .

Finney, D. J. (1947) Probit Analysis, pp. 65-72. Cambridge University Press.

Fujino, M., Yamazaki, I., Kobayashi, S., Fukuda, T., Shinagawa, S., Nakayama, R., White, W. F. \& Ripper, R. H. (1974a) Some analogues of luteinizing hormone-releasing hormone (LH-RH) having intense ovulation-inducing activity. Biochem. biophys. Res. Commun. 57, 1248-1256.

Fujino, M., Fukuda, T., Shinagawa, S., Kobayashi, S., Yamazaki, I., Nakayama, R., Seely, J. H., White, W. F. \& Rippel, R. H. (1974b) Synthetic analogues of luteinizing hormone-releasing hormone (LH-RH) substituted in position 6 and 10. Biochem. biophys. Res. Commun. 60, 406-413.

Humphrey, R. R., Dermody, W. C., Brink, H. O., Bousley, F. G., Schotrin, N. H., Sakowski, R., Vattkus, J. W., Veloso, H. T. \& Reel, J. R. (1973) Induction of luteinizing hormone (LH) release and ovulation in rats, hamsters and rabbits by synthetic luteinizing hormone-releasing factor (LRF). Endocrinology, 92, 1515-1525.

Immer, H., Nelson, V. R., Revesz, C., SestanJ, K. \& Götz, M. (1974) Luteinizing hormone-releasing hormone and analogues: synthesis and biological activity. f. med. Chem. 17, 1060-1065.

Kastin, A. J., Schally, A. V., Gonzalez-Barcena, D., Coy, D. H., Miller, M. G., Portas, H. \& SchaLCH, D. S. (1974) Clinical comparison of natural LH-RH, synthetic LH-RH and two analogues of LH-RH. 7. clin. Endocr. Metab. 38, 801-804.

LABhsETwAR, A. P. (1973) Pituitary gonadotrophic function (FSH and LH) in various reproductive states. Adv. Reprod. Physiol. 6, 97-183.

Matnland, D. \& Murray, I. M. (1952) Tables for use of fourfold contingency tests. Science, N.r. 116, 591-594.

Matsuo, H., Arimura, A., Nair, R. M. G. \& Schally, A. V. (1971) Synthesis of the porcine LH- and FSH-releasing hormone by the solid-phase method. Biochem. biophys. Res. Commun. 45, 822-827.

Morishita, H., Mitani, H., Masuda, Y., Higuchi, K., Tomioka, M., Nagamaghi, N., Kawamoto, M., OzASA, T. \& ADACHI, H. (1974) Effect of synthetic luteinizing hormone releasing hormone on ovulation during the oestrous cycle in the rat. Acta endocr., Copenh. 76, 431-437. 
Neguin, L. G., Talley, W. L., ManN, B. G. \& Schwartz, N. B. (1974) Measurement of serum LH during the pro-estrous critical period in rats exhibiting four or five-day estrous cycles. Neuroendocrinology, 14, 65-71.

Schally, A. V., Kastin, A. J. \& Arimura, A. (1971) Hypothalamic FSH- and LH-releasing hormone; structure, physiology and clinical studies. Fert. Steril. 22, 703-721.

Schwartz, N. B. (1974) The role of FSH and LH and their antibodies in follicular growth and on ovulation. Biol. Reprod. 10, 236-272.

Short, R. V. (1964) Ovarian steroid synthesis and secretion in vivo. Recent Progr. Horm. Res. 20, 303-340.

TAYMor, M. L., Berger, M. J., Thompson, I. E. \& KaraM, K. S. (1972) Hormonal factors in human ovulation. Am. 7. Obstet. Gynec. 114, 445-452.

White, W. F., Hedlund, M. T., Rippei, R. H., Arnold, W. \& Flouret, G. R. (1973) Chemical and biological properties of gonadotropin-releasing hormone synthesized by the solid-phase method. Endocrinology, 93, 96-106. 